\title{
Antifungal Studies of Selected Essential Oils and a Commercial Formulation against Botrytis Cinerea
}

\author{
Oyeboade Adebayo ${ }^{1,2}$, Thao Dang ${ }^{2}$, André Bélanger ${ }^{2} \&$ Shahrokh Khanizadeh ${ }^{2,3}$ \\ ${ }^{1}$ National Horticultural Research Institute, Ibadan, Nigeria \\ 2 Horticultural Research and Development Centre, Agriculture and Agri-Food Canada, Gouin Blvd., \\ Saint-Jean-sur-Richelieu, QC, Canada \\ Correspondence: Shahrokh Khanizadeh.E-mail: shahrokh.khanizadeh@agr.gc.ca
}

Received: October 17, 2012 Accepted: January 9, 2013 Online Published: January 28, 2013

doi:10.5539/jfr.v2n1p217

URL: http://dx.doi.org/10.5539/jfr.v2n1p217

\begin{abstract}
Growing concerns about food safety and environmental protection have created a need for new and safe plant disease control strategies. The aim of this study was to find an alternative to synthetic fungicides currently used in the control of the devastating fungal pathogen Botrytis cinerea Pers., the causal agent of grey mould disease of strawberry (Fragariaananassa Duch). The antifungal activity of the essential oils of Origanumvulgare L., Monardadidyma L. and of a commercial formulation of thyme oil (Gloves Off $®$ ) was investigated against $B$. cinerea and compared with controls. Contact phase effects of different concentrations of the essential oils and commercial formulation were found to inhibit the growth of $B$. cinerea in a dose dependent manner. Complete growth inhibition of the pathogen was recorded at $200 \mu \mathrm{g} / \mathrm{ml}$ of 'Gloves Off®'. The mycelial growth of the pathogen was significantly reduced at the highest concentration of the essential oils of $O$. vulgare and $M$. didyma tested, which was $51.2 \mu \mathrm{g} / \mathrm{ml}$. Spore germination and germ tube elongation were also inhibited by the essential oils and Gloves Off ${ }^{\circledR}$. Light microscopic observations revealed that the essential oils caused morphological degenerations, such as cytoplasmic coagulation, hyphal shrivelling and protoplast leakage of the fungal hyphae. The essential oils of $O$. vulgare $\mathrm{L}$. and $M$. didyma L. are promising, antifungal agents against $B$. cinereasimilar to the commercial formulation 'Gloves Off®'.
\end{abstract}

Keywords: antifungal activity, Botrytis cinerea, Monardadidyma, Origanumvulgare, strawberry

\section{Introduction}

Gray mould disease caused by Botrytis cinerea Pers.is a major constraint to cultivation of strawberry (Fragariaananassa Duch) globally (Elad, Williamson, Tudzynski, \& Delen, 2004). It infects the plant both during growing season and during storageand causes up to $55 \%$ loss during post-harvest storage (Martinez-Romero et al., 2007). Chemical control was the main control measure used until the mid-1990s. Site specific fungicides belonging to the benzimidazole, dicarboximide and $\mathrm{N}$-phenylcarbamatefamilies were used alone or in rotation with multi specific inhibitors, such as chlorothalonil, iminoctadine, captan and dichlofluanid (Leroux et al., 2002). Although these synthetic chemicals are quick-acting and effective, their continued use has led to resistance to various types of chemicals (Beever, Laracy, \& Pak, 1989; Elad, Yunis, \& Katan, 1992; Brent \& Hollomon, 1998), residues in food, toxicity to non-target organisms and environmental problems. Growing concerns about food safety and environmental protection have created the need for the development of new and safe control strategies.

Essential oil bearing plants constitute a rich source of bioactive chemicals, which have been reported to have various antifungal properties (Daferera, Ziogas, \& Polissiou, 2003; Kalemba \& Kunicka, 2003). These chemicals are often active against a limited number of species, including the specific target species.They are also biodegradable and non-toxic. The antifungal and antibacterial activity of oregano essential oil against a number of plant pathogens has been reported, such as Aspergillusnigerv. Tieghem, Aspergillusflavus Link, Aspergillusochraceus Wilhelm (Paster, Menasherov, Ravid, \& Juven, 1995), A. niger, Fusariumoxysporum Snyder and Hansen, Penicilliumsps L. (Daouk, Dagher, \& Sattout, 1995), Pseudomonas aeruginosa Schroter ATCC 2730 and Staphylococusaureus Rosenbach ATCC 6538 (Lambert, Skandamis, Coote, \& Nychas, 2001), Fusariumsolani var. coeruleum (Martius) Saccardoand Clavibactermichiganensis S. (Daferera et al., 2003), Phytophtorainfestans Mont. (E. Soylu, Soylu, \& Kurt, 2006), Sclerotiniasclerotiorum Lib. (S. Soylu, Yigitbas, 
Soylu, \& Kurt, 2007) and Xanthomonasvesicatoria D. (Vansinauskiene, Radusiene, Zitikaite, \& Surviliene, 2006). The sensitivity of B. cinerea to the essential oil of different species of Oregano like Origanumvulgare L. (Daferera et al., 2003) and Origanumsyriacum L. (E. Soylu, Kurt, \& Soylu, 2010), has also been reported.

Similarly, plants in the genus Monarda produce complex essential oils that contain antifungal compounds and are reported to inhibit the growth of Rhizoctoniasolani K. (Fraternale at al., 2006; Gwinn et al., 2010) and Sclerotiniasclerotionum (Gwinn, Greene, Trently, \& Ownley, 2006). However to date, no study has been done to investigate the effect of essential oils of Monardaon B. cinerea.

Although several essential oils have been reported to have antifungal properties, few have been developed as commercial formulations for use in plant disease control. Biomor Israel Ltd. developed a new organic formulation BM-608 containing 23.8\% of Melaleucaalternifolia oil, which is effective against a broad spectrum of plant diseases in various crops. Reuveni, Neifeld, Dayan and Kotzer (2009) reported its use for the control of fungal diseases in tomato with no phytotoxicity to plant foliage.

In this study, we examined the effects ofessential oil of two species, oregano and monarda, as well as that of 'Gloves Off®', a commercial formulation presently sold in Quebec, Canada. Gloves Off $®$ contains essential oils, with thymol and carvacrol as its active ingredients, which inhibits mycelium growth and spore germination of $B$. cinerea. Results from the study will provide information on effective essential oils for the control of gray mould of strawberry.

\section{Materials and Methods}

\subsection{Chemicals}

Potato dextrose agar (PDA) waspurchased from Sigma-Aldrich (St. Louis, MO, USA), while Tween 20 was the product of Agdia. Gloves Off $\AA$, is a commercial disinfectant produced by Planet People and Laboratoire $\mathrm{M}^{2}$, INC (Sherbrooke, QC, Canada).

\subsection{Plant Material and Characterization of Essential Oils}

For the extraction of essential oils, plants of (O. vulgare L., and Monardadidyma L.) were collected from field accessions growing at the L'Acadie $\left(45^{\circ} 17^{\prime} \mathrm{N} ; 73^{\circ} 20^{\prime} \mathrm{W}\right)$, the experimental station of the AAFC's Horticultural Research and Development Centre in Saint-Jean-sur-Richelieu, Canada. The composition of the essential oils was determined using gas chromatography and mass spectrometry (GC-MS) analysis.

\subsection{Test Fungi}

Botrytis cinereapreviously isolated from diseased strawberry was provided by the Phytopathology Laboratory of AAFC's Horticultural Research and Development Centre in Saint-Jean-sur-Richelieu. Stock cultures were maintained on potato dextrose agar slants and sub cultured once a month

\subsection{Determination of Antifungal Activities}

The antifungal properties of the essential oils and commercial formulation were evaluated for their contact effect on the mycelium growth of $B$. cinerea using the method of E. Soylu et al. (2010). Different concentrations were prepared by dissolving various amounts of oregano and monarda essential oils in $1 \mathrm{ml}$ of ethanol $(0.5 \%)$ and Tween $20(0.1 \%)$. The commercial formulation was used without any emulsifier; $20 \mathrm{ml}$ of the amended medium was transferred to each sterile glass petri dish $\left(90 \times 20 \mathrm{~mm}\right.$ in diameter) at a temperature of $40-45^{\circ} \mathrm{C}$. The essential oils were tested at $0.8,3.2,12.8$ and $51.2 \mathrm{ug} / \mathrm{ml}$, while the commercial formulation was tested at 50,100,150 and $200 \mathrm{ug} / \mathrm{ml}$. The controls received the same quantity of ethanol and Tween 20 mixed with and PDA and only sterile distilled water. Potato dextrose agar discs $(7 \mathrm{~mm}$ diameter) from the edge of a 7 day old $B$. cinereaculture were used to inoculate the centre of each plate. Plates were incubated in the dark at $22^{\circ} \mathrm{C}$ for 7 days. For each treatment and concentration, 5 replicate plates were used. The mean radial mycelium growth was measured with a Verniercaliper by measuring the diameter of the colony in two directions at right angles.

\subsection{Effect on Conidia Germination and Germ Tube Elongation}

The effects of the essential oil and commercial formulation on spore germination and germ tube elongation of $B$. cinerea were as described by E. Soylu et al. (2010). A spore suspension $\left(10^{4}\right.$ spores $\left.\mathrm{ml}^{-1}\right)$ of $B$. cinerea was prepared from actively growing culture (7-8 days old) in sterile distilled water using a haemocytometer. Three different $50 \mu \mathrm{l}$ aliquots of the spore suspension drops were spread on PDA medium supplemented with different concentrations of the essential oils and commercial formulation. Sterile distilled water alone and sterile distilled water with ethanol and Tween 20 were used as controls. Plates were incubated at $22^{\circ} \mathrm{C}$ for $10-12$ hours, after which germination was stopped by applying a drop of lacto phenol-cotton blue to the inoculation sites on plates. The percentage of spore germination and the lengths of germ tubes were estimated under a microscope. The 
percent inhibition was calculated in relation to the respective control. Three replicates of each treatment were performed and the experiments were repeated twice.

\subsection{Determination of Treatments Effects on Hyphal Morphology}

Thin layers $(1 \mathrm{~mm})$ of agar blocks were removed for examination under light microscopy. The block cuts from growing edges were placed in a drop of lacto phenol on microscope glass slides, covered with cover slips and examined using a phase contrast light microscope (Olympus BX41, Tokyo, Japan).

\subsection{Statistical Analysis}

Each experiment was analysed separately and the two sets of data were pooled together after testing the homogeneity of the two experimental errors. The efficacy of the selected levels was tested and a least significant difference (LSD) test was used to separate means for each time interval tested using SAS, GLM procedure (SAS Institute, 1989).

\section{Results}

\subsection{Composition of the Essential Oils}

The chemical composition of the essential oils used, as determined by GC-MS analysis is shown in Table 1. The essential oils were characterized by the presence of major compounds such as thymol, carvacrol, para-myrcene, $\gamma$-terpinene, $\alpha$-terpinene, $\alpha$-thujene, $\beta$-myrcene. Thymol (41.17\%) was the main compound found in the monardaessential oil, while carvacrol (37.03\%) was the main compound found in the oregano essential oil.

Table 1. Chemical composition for the essential oils from Oregano and Monarda

\begin{tabular}{llll}
\hline & & \multicolumn{2}{c}{ Composition (\%) } \\
\cline { 3 - 4 } Component & Retention time (min) & Origanumvulgare & Monardadidyma \\
\hline$\alpha$-Thujene & 5.55 & 4.07 & 2.62 \\
$\alpha$-Pinene & 5.67 & 1.91 & 0.73 \\
$\beta$-myrcene & 7.07 & 4.58 & 2.489 \\
$\alpha$-phellandrene & 7.41 & 0.60 & 0.47 \\
$\alpha$-Terpinene & 7.73 & 3.87 & 4.58 \\
para-myrcene & 7.95 & 14.26 & 12.58 \\
Limonène & 8.06 & 1.47 & 1.53 \\
Y-terpinène & 8.88 & 18.14 & 15.88 \\
Sabinene & 9.11 & 0.00 & 0.57 \\
1-terpinene-4-ol & 12.17 & 0.81 & 0.64 \\
Thymylméthyléther & 14.0 & 0.00 & 1.18 \\
Thymol & 15.40 & 10.40 & 41.17 \\
Carvacrol & 15.65 & 37.03 & 15.20 \\
caryophyllène & 18.44 & 2.88 & 0.000 \\
germacrene-D & 19.62 & 0.00 & 0.37 \\
Total & & 100.0 & 100.0 \\
\hline
\end{tabular}

\subsection{Antifungal Activities of Essential Oils on Mycelial Growth}

The effects of different concentrations of the essential oils on mycelial growth of $B$. cinerea are shown in Table 2. All of the essential oils inhibited the growth of $B$. cinerea in a dose dependent manner. 'Gloves Off $($ ' achieved complete growth inhibition at higher concentrations of 150 and $200 \mu \mathrm{g} / \mathrm{ml}$. Concentrations of 'Gloves Off ${ }^{\circledR}$ ' of 50 and $100 \mu \mathrm{g} / \mathrm{ml}$ inhibited growth for 24 and 48 hours respectively, after which continued mycelial growth occurred. Although growth in essential oils amended plates had a significantly lower mycelial diameter, complete growth inhibition was achieved at the highest concentration tested $(51.2 \mu \mathrm{g} / \mathrm{ml})$ only for 24 hours (Table 2). 
Table 2. Effect of oregano, monarda essential oil and 'Gloves Off®' on mycelial growth of Botrytis cinerea

\begin{tabular}{llllll}
\hline \multirow{2}{*}{ Concentration $(\mu \mathrm{g} / \mathrm{ml})$} & \multicolumn{5}{c}{ Mycelial Growth Diameter (cm) } \\
\cline { 2 - 6 } Oregano & $24 \mathrm{~h}$ & $48 \mathrm{~h}$ & $72 \mathrm{~h}$ & $96 \mathrm{~h}$ & $120 \mathrm{~h}$ \\
0 & 1.69 & 3.26 & 4.36 & 6.04 & 7.09 \\
3.2 & 1.66 & 3.23 & 4.16 & 5.65 & 6.97 \\
12.8 & 1.51 & 3.13 & 4.03 & 5.58 & 6.93 \\
51.2 & 0 & 1.48 & 2.04 & 2.86 & 3.78 \\
LSD & 0.14 & 0.32 & 0.50 & 0.45 & 0.42 \\
Monarda & & & & \\
0 & 1.76 & 3.26 & 4.45 & 6.07 & 6.94 \\
3.2 & 1.40 & 2.92 & 4.26 & 5.34 & 6.70 \\
12.8 & 1.20 & 2.73 & 4.08 & 5.24 & 6.31 \\
51.2 & 0 & 1.03 & 1.83 & 2.53 & 3.31 \\
LSD & 0.19 & 0.33 & 0.32 & 0.52 & 0.37 \\
Gloves Off® & & & & & \\
0 & 1.95 & 4.40 & 7.01 & 7.67 & 8.2 \\
50 & 0 & 1.02 & 1.58 & 2.48 & 3.21 \\
100 & 0 & 0 & 0.95 & 1.48 & 1.91 \\
150 & 0 & 0 & 0 & 0 & 0 \\
200 & 0 & 0 & 0 & 0 & 0 \\
LSD & 0.06 & 0.07 & 0.22 & 0.31 & 0.27 \\
\hline & & & & & \\
\hline
\end{tabular}

\subsection{Effect of Essential Oil on Conidia Germination and Germ Tube Elongation}

The effects of the various concentrations of the essential oils and commercial formulation on conidia germination and germ tube elongation are shown in Figures 1-3. The trend was similar to that recorded with mycelial growth. Higher inhibitory activities were recorded with the commercial formulation. Although percentage germination and germ tube length were significantly reduced with each tested concentration, complete germination inhibition was achieved at higher concentrations of 150 and $200 \mu \mathrm{g} / \mathrm{ml}$. Complete germination inhibition was not achieved with the essential oils although significantly lower percentage germination and germ tube lengths were associated with increased concentrations of the essential oils.

\subsection{Effects of Oils on Hyphal Morphology}

Microscopic observation of hyphae grown on PDA amended with the essential oils and Gloves Off® showed degenerative changes in hyphal morphology compared with the control (Figure 4). Healthymycelium grown on PDA medium presented a normal morphology with smooth, linear, homogeneous cell wallhypha. However, these normal morphological structures varied in the presence of the essential oils and commercial formulation. Shrivelled hyphal cells with cytoplasmic coagulation or even no cytoplasm were observed. In some cases cell wall disruption and consequent cell death were recorded (Figure 4).

\section{Discussion}

In recent years, interest has been generated in the developmentof safer antifungal agents such as plant-based essential oilsand extracts to control phytopathogens in agriculture (Costa et al., 2000). As a matter of fact, volatile essential oils from several medicinal plants have been reported. 

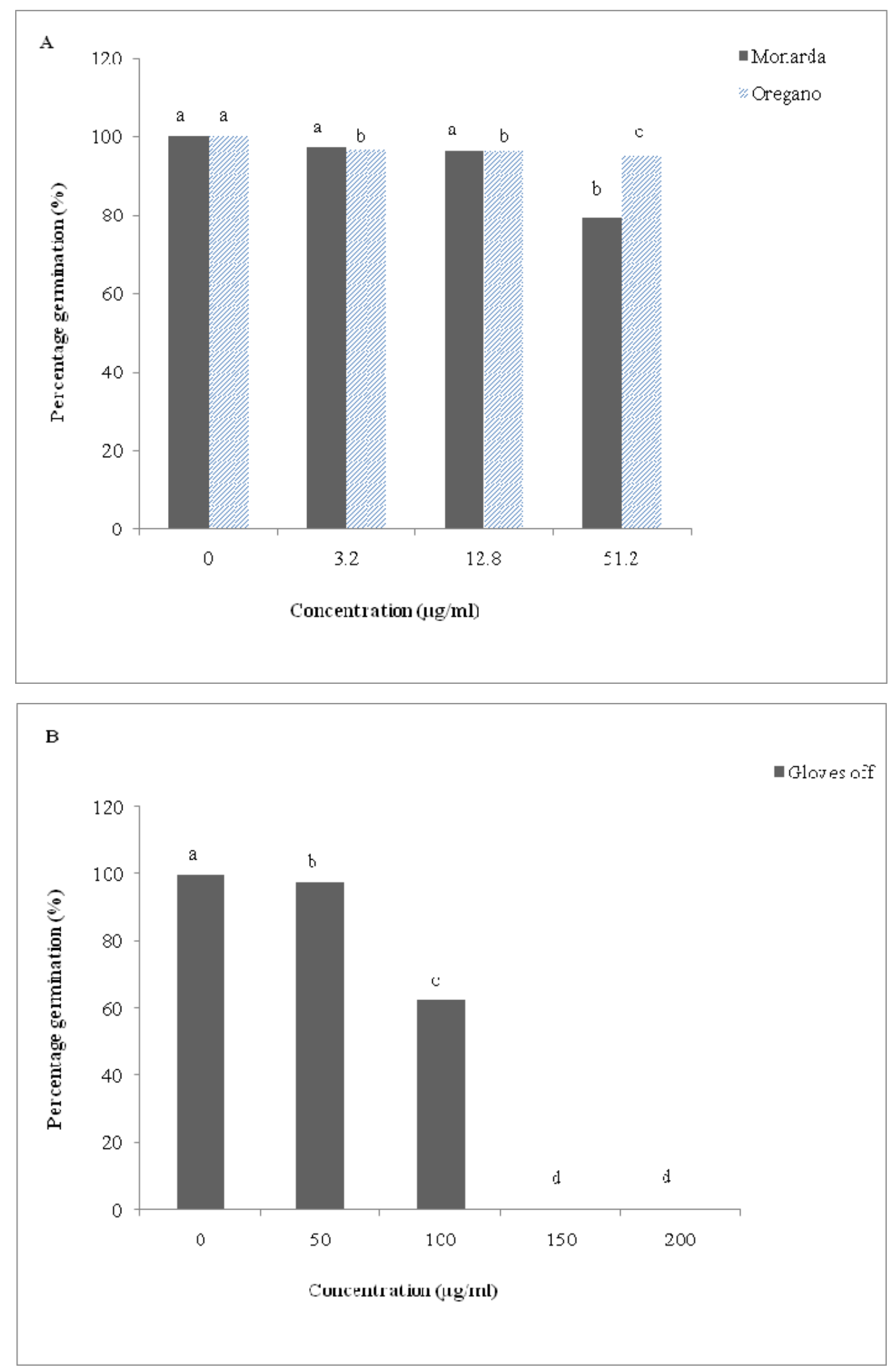

Figure 1. Spore germination in cultures amended with (A) Monarda and Oregano (B) Gloves Off $®$

Bars of each essential oil with the same letters represent values which are not significantly different according to $\mathrm{t}$ test $(\mathrm{P} \leq 0.05)$. 

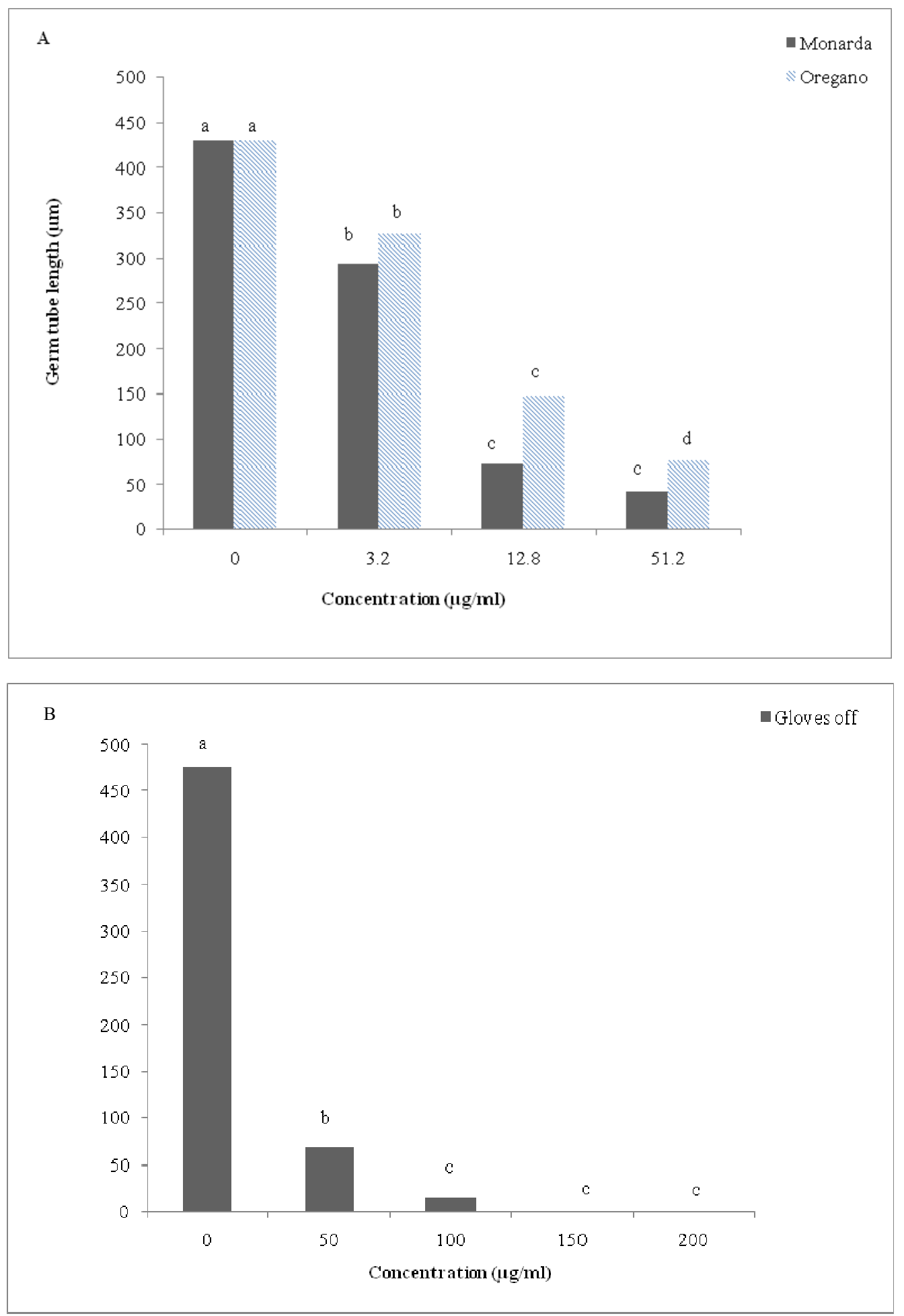

Figure 2. Germ tube length in cultures amended with (A) Monarda and Oregano (B) Gloves Off $₫$

Bars of each essential oil with the same letters represent values which are not significantly different according to $t$ test $(P \leq 0.05)$. 

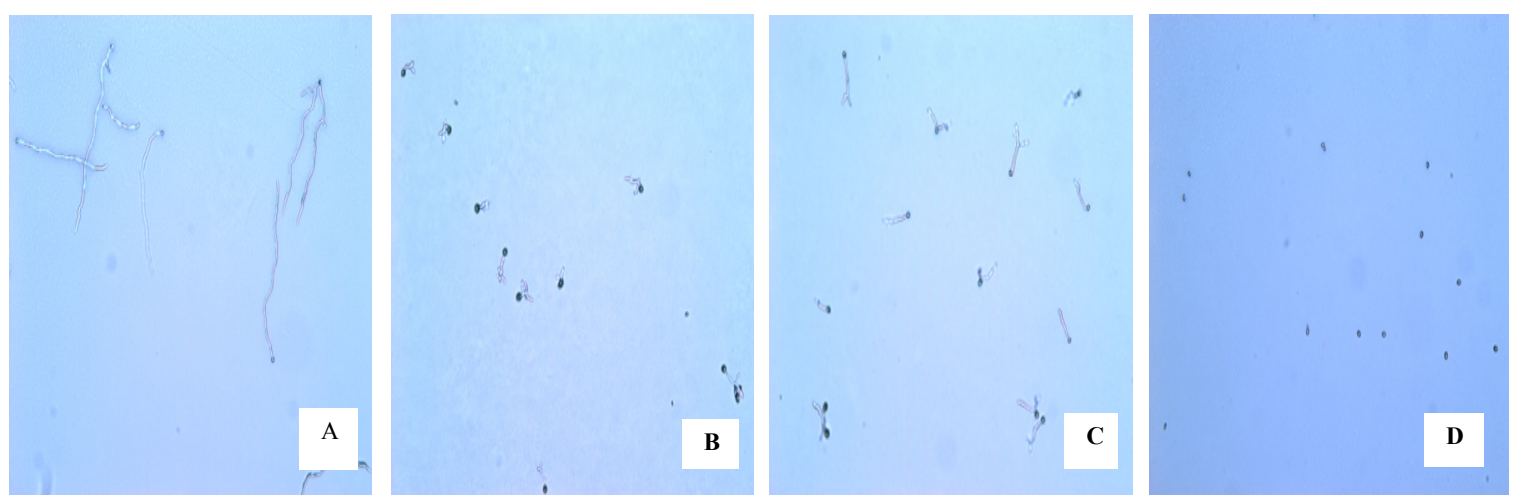

Figure 3. Light micrographs of conidia germination and germ tube length of Botrytis cinerea grown in (A) Control (B) Monarda EO (C) Oregano EO (D) 'Gloves Off®' with EO as active ingredient
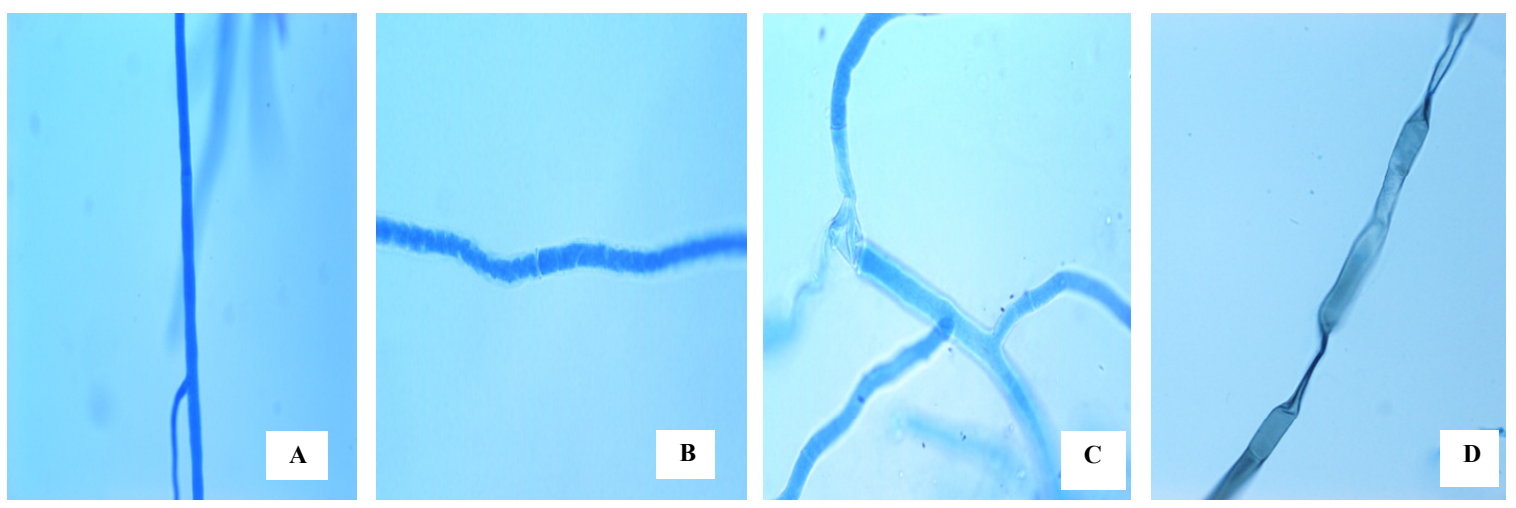

Figure 4. Hyphal morphology of Botrytis cinerea grown in (A) control (B) Monarda EO (C) Oregano EO (D)

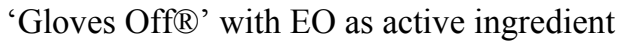

In this study, we found that 'Gloves off ${ }^{2}$ ' and essential oils from oregano and monarda inhibited spore germination and mycelial growth of $B$. cinerea. The efficacy was positively correlated with the concentration of the solution (Table 1, Figures 1 and 2). These results confirm the literature data about the effectiveness of plant essential oils extracted by hydro-distillation from aromatic plants on the growth of a wide range of plant pathogenic fungi and bacteria (Daferera et al., 2003). It also suggests the inhibitory efficacy of commercial products derived from such plants against the growth and spore germination of $B$. cinerea. These inhibitory activities may be linked to the chemical composition of both Gloves Off ${ }^{\circledR}$ and the essential oils of oregano and monarda. In our study, the major constituents of the oregano and monarda essential oilsand the 'Gloves off®' were carvacrol and thymol. This indicated that the two plants tested can be good sources of carvacrol and thymol for the development of safe fungicides. Various studiesconcerning the genus Origanum have shown that its oils possess strong antimicrobial activity, which is attributed to their high percentageof phenolic compounds, specifically carvacrol, thymol, pcymeneand their precursor c-terpinene (Sivropoulou et al., 1996; Davidson \& Naidu, 2000). Specific studies have linked these compounds to antifungal activities against $B$. cinerea. Bouchra, Achouri, Hassaniand Hmamouchi (2003) reported that the essential oils of seven Moroccan Labiatae consists mainly of carvacrol, linalyl acetate and thymol as major components, and exhibiteda complete mycelial inhibition effect on the growth of $B$. cinerea. In another study, carvacrol, thymol and citral were again reported to show complete inhibition of $B$. cinerea (Plotto, Roberts, \& Roberts, 2003).

Data for typical essential oil contents and composition of O.vulgare are abundant with variable results in terms of chemical composition. Ferreira et al. (1998) reported that the essential oil of $O$. vulgaresubsp. Virens is not rich incarvacrol. However, Salgueiro et al. (2003) studied a carvacrol-rich O. vulgaresubsp. Virens and its activity on Candidaalbicans. Figueredo, Cabassu, Chalchat and Pasquier (2006) reported that there are significant differences in the yield and composition of essential oils from populations of $O$. vulgare arising from environmental factors, the most important of which is altitude, relating this to lack of water and shortgrowing 
periods. We report here in our study the composition of $O$. vulgare, with carvacrol $(37 \%)$ as its major constituent, as well as an appreciable amount of thymol (10.4\%).

Essential oils collected from $M$. didymahave also been reported to be effective antifungal agents in previous studies, the primary constituent of the essential oils wasthymol (Fraternale et al., 2006), which is consistent with what we found in our study.

Apart from the positive value of each of the chemical components of the essential oils identified, there seems to be a synergy between some of the chemical constituents of the oregano and monarda essential oils tested in our study, making them more effective and low risk in terms of the development of resistance by plant pathogenic fungi. In fact, Daferera et al. (2003) reported that it is very difficult for the fungi to develop resistance to such a mixture of oil components with different mechanisms of antimicrobial activity. For instance the biological precursors of carvacrol, $\gamma$-terpinène and p-cymene, are not effective antibacterial agent when used alone; however, when combined with carvacrol, synergism has been observed (Ultree, Bennink, \& Moezelaar, 2002). The greater efficiency of p-cymenewas reported to facilitate the transport of carvacrol across the cytoplasmic membraneof fungi (Morcia et al., 2011). They also concluded that thymol, eugenol and carvone are highly active in the in vitro control of fungal species responsible for mycotoxin contamination of economically valuable crops (Morcia et al., 2011).

Light observations of hyphae of $B$. cinerea exposed to essential oils revealed alterations in hyphal morphology. Shrivelled hyphal aggregates reduce dhyphal diameters and lyses of hyphal wall were commonly observed in mycelium treated with oregano and monarda essential oils and Gloves Off $囚$, compared with thick, elongated, normal mycelial growth in controls. E. Soylu et al. $(2007,2010)$ suggested that such modifications may be related to theeffect of the essential oil as enzymatic reactions regulating wall synthesis. The lipophilic properties of essential oil components might have also aided its ability to penetrate the plasma membrane (Knobloch, Pauli, Iberl, Weigand, \& Weiss, 1989). The observations made with lightmicroscopy are in accordance with previous studies in which essential oils of aromatic plants caused morphological alterations on the fungal hyphae (Bianchi et al., 1997; Fiori et al., 2000; Romagnoli et al., 2005; E. Soylu et al., 2005; E. Soylu et al., 2006; E. Soylu et al., 2010).

In future work, it will be crucialto determine the concentration and timing of application of these essential oils and the commercial formulation for successful gray mould disease control in detailed field evaluations. There will also be need for phytotoxic test on these products.

In conclusion, oregano and monarda mediated essential oil and Gloves Off® could be applied as an alternative to synthetic fungicides for the control of $B$. cinerea. They could also be screened to develop such novel types of selective and natural fungicides in the safe control of many agricultural plant pathogens causing drastic crop losses.

\section{References}

Beever, R. E, Laracy, E. P., \& Pak, H. A. (1989). Strains of Botrytis cinerea resistant to dicarboximide andbenzimidazole fungicides in New Zealand vineyards. Plant Pathology, 38, 427-437. http://dx.doi.org/10.1111/j.1365-3059.1989.tb02163.x

Bianchi, A., Zambonelli, A., D’Aulerio, A. Z., \& Bellesia, F. (1997). Ultrastructural studies of the effects of Allium sativum on phytopathogenic fungi in vitro. Plant Diseases, 81, 1241-1246. http://dx.doi.org/10.1094/PDIS.1997.81.11.1241

Bouchra, C., Achouri, M., Hassani, L. M. I., \& Hmamouchi, M. (2003). Chemical composition and antifungal activity of essential oils of seven Moroccan Labiatae against Botrytis cinerea Pers. J. Ethnopharmacol, 89, 165-169. http://dx.doi.org/10.1016/S0378-8741(03)00275-7

Brent, K. J., \& Hollomon, D. W. (1998). Fungicide resistance: the assessment of risk. FRAC, Global Crop Protection Federation, Brussels, Monograph, 2, pp. 1-48.

Costa, T. R., Fernandes, F. L. F., Santos, S. C., Oliveria, C. M. A., Liao, L. M., Ferri, P. H., ... Silva, M. R. R. (2000). Antifungal activity of volatile constituents of Eugenia dysenterica leaf oil. J. Ethnopharmcol, 72(2), 111-117. http://dx.doi.org/10.1016/S0378-8741(00)00214-2

Daferera, D. J., Ziogas, B. N., \& Polissiou, M. G. (2003). The effectiveness of plant essential oils on the growth of Botrytis cinerea, Fusarium sp. and Lavibacter michiganensis sub sp. michiganensis. Crop Protection, 22, 39-44. http://dx.doi.org/10.1016/S0261-2194(02)00095-9 
Daouk, R. K., Dagher, S. M., \& Sattout, E. J. (1995). Antifungal activity of the essential oil of Origanumsyriacum L. Journal of Food Protection, 58, 1147-1149.

Davidson, P. M., \& Naidu, A. S. (2000). Phyto-phenols. In A. S. Naidu (Ed.), Natural Food Antimicrobial System (pp. 265-294). Boca Raton, FL: CRC Press.

Elad, Y., Williamson, B., Tudzynski, P., \& Delen, N. (2004). Botrytisspp and diseases they cause in agricultural systems an introduction. In Y. Elad, B. Williamson, P. Tudzynski, \& N. Delen (Eds.), Botrytis: Biology, pathology and control (pp. 1-8). The Netherlands: Kluwer Academic Publishers Dordrecht.

Elad, Y., Yunis, H., \& Katan, T. (1992). Multiple resistance to benzimidazolesdicarboximides and diethofencarb in field isolates of Botrytis cinerea in Israel. Plant Pathology, 41, 41-46. http://dx.doi.org/10.1111/j.1365-3059.1992.tb02314.x

Ferreira, P., Gaspar, F., Sousa, C., Bernardo-Gil, G., Empis, J. A., Rouzet, M., ... Bastos, J. (1998). Origanumvirensan oregano from Portugal. AIR e Agro Industrial Research, European Project AIR3CT93e0818. Lisboa: European Commission eDG XII e Science, Research and Development, IST.

Figueredo, G., Cabassu, P., Chalchat, J. C., \& Pasquier, B. (2006). Studies of Mediterranean oregano populations, VIII e chemical composition of essential oils of oreganos of various origins. Flavour and Fragrance Journal, 21, 134-139. http://dx.doi.org/10.1002/ffj.1543

Fiori, A. C. G., Schwan-Estrada, K. R. F., Stangarlin, J. R., Vida, J. B., Scapim, C. A., Cruz, M. E. S., \& Pascholati, S. F. (2000). Antifungal activity of leaf extracts and essential oils of some medicinal plants $\begin{array}{lllll}\text { against Didymellabryoniae. Journal of Phytopathology, } & \text { 148, }\end{array}$ http://dx.doi.org/10.1046/j.1439-0434.2000.00524.x

Fraga, C. G., Galleano, M., Verstraeten, S. V., \& Oteiza, P. I. (2010). Basic biochemical mechanisms behind the health benefits of polyphenols. Mol. Aspects Med., 31, 435-445. http://dx.doi.org/10.1016/j.mam.2010.09.006

Fraternale, D., Giamperi, L., Bucchini, A., Ricci, D., Epifano, F., Burini, G., \& Curini, M. (2006). Chemical composition, antifungal and in vitro antioxidant properties of Monardadidyma L. essential oil. J. Essen. Oil Res., 18, 581-585. http://dx.doi.org/10.1080/10412905.2006.9699174

Gwinn, K. D., Greene, S. E., Trently, D. J., \& Ownley, B. H. (2006). Inhibition of sclerotia of Sclerotiniasclerotiorum by Monarda and its essential oils constituents.(Abstr.) Phytopathology, 96, S44.

Gwinn, K. D., Ownley, B. H., Greene, S. E., Clark, M. M., Taylor, C. L., Springfield, ... Hamilton, S. (2010). Role of essential oils in control of Rhizoctonia damping-off in tomato with bioactive monarda herbage. Phytopathology, 100, 493-501. http://dx.doi.org/10.1094/PHYTO-100-5-0493

Hébert, C., Charles, M. T., Gauthier, L., Willemot, C., Khanizadeh, S., \& Cousineau, J. (2002). Strawberryproanthocyanidins: biochemical markers for Botrytis cinerearesistance and shelf-life predictability. ActaHort., 567, 659-662.

Kalemba, D., \& Kunicka, A. (2003). Antibacterial and antifungal properties of essential oils. Current Medicinal Chemistry, 10, 813-829. http://dx.doi.org/10.2174/0929867033457719

Khanizadeh, S., Cousineau, J., Gauthier, L., Buszard, D., \& Hébert, C. (2002). "L' Authentique Orleans": A new strawberry cultivar with high level of antioxidant. Acta Hort., 567, 175-176.

Khanizadeh, S., Tao, S., Zhang, S., Tsao, R., Rekika, D., Yang, R., \& Charles, M. T. (2008). Antioxidant activities of newly developed day-neutral and June-bearing strawberry lines. J. of Food.Agr.andEnvir., 6(2), 306-311.

Knobloch, K., Pauli, P., Iberl, B., Weigand, H., \& Weiss, N. (1989). Antibacterial and antifungal properties of essential oil components.Journal of Essential Oil Research, 1, 119-128. http://dx.doi.org/10.1080/10412905.1989.9697767

Lambert, R. J. W., Skandamis, P. N., Coote, P. J., \& Nychas, G. J. E. (2001). A study of the minimum inhibitory concentration and mode of action of oregano essential oil, thymol and carvacrol. J. Applied Microbiol, 91, 453-462. http://dx.doi.org/10.1046/j.1365-2672.2001.01428.x

Leroux, P., Fritz, R., Debieu, D., Albertini, C., Lanen, C., Bach, J., ... Chapeland, F. (2002). Mechanisms of resistance to fungicides in field strains of Botrytis cinerea. Pest Management Science, 58, 876-888. http://dx.doi.org/10.1002/ps.566 
Martínez-Romero, D., Guillén, F., Valverde, J. M., Bailén, G., Zapata, G., Serrano,M., ... Valero, D. (2007). Influence of carvacrol on survival of Botrytis cinereainoculated in table grapes. International Journal of Food Microbiology, 115(2), 144-148. http://dx.doi.org/10.1016/j.ijfoodmicro.2006.10.015

Morcia, C., Malnati, M., \& Terzi, V. (2012). In vitro antifungal activity of terpinen-4-ol, eugenol, carvone, 1,8-cineole (eucalyptol) and thymol against mycotoxigenic plant pathogens pathogens. Food Additives and Contaminants: Part A: Chemistry, Analysis, Control, Exposure and Risk Assessment, 29(3), 415-422.

Paster, N., Menasherov, M., Ravid, U., \& Juven, B. (1995). Antifungal activity of oregano and thyme essential oils applied as fumigants against fungi attacking stored grain. Journal of Food Protection, 58(1), 81-85.

Plotto, A., Roberts, D. D., \& Roberts, R. G. (2003). Evaluation of plant essential oils as natural postharvest disease control of tomato (Lycopersiconesculentum). ActaHortic., 628, 737-745.

Reuveni, M., Neifeld, D., Dayan, D., \& Kotzer, Y. (2009). BM- 608-A novel organic product based on essential tea tree oil forthe control of fungal diseases in tomato. Acta Hort., 808, 129-132.

Romagnoli, C., Bruni, R., Andreotti, E., Rai, M. K., Vicentini, C. B., \& Mares, D. (2005). Chemical characterization and antifungal activity of essential oil of capitula from wild Indian Tagetespatula L. Protoplasma, 225, 57-65. http://dx.doi.org/10.1007/s00709-005-0084-8

Salgueiro, L. R., Cavaleiro, C., Pinto, E., Pina-Vaz, C., Rodrigues, A. G., \& Palmeira, A. (2003). Chemical composition and antifungal activity of the essential oil of Origanumvirens on Candida species. Planta Medica, 69(9), 871-874.

Sivropoulou, A., Papanikolaou, E., Nikolaou, C., Kokkini, S., Lanaras, T., \& Arsenakis, M. (1996). Antimicrobial and cytotoxic activities of Origanum essential oils. Journal of Agricultural and Food Chemistry, 44(5), 1202-1205. http://dx.doi.org/10.1021/jf950540t

Soylu, E. M., Kurt, S., \& Soylu, S. (2010). In vitro and in vivo antifungal activities of the essential oils of various plants against tomato grey mould disease agent Botrytis cinerea. International Journal of Food Microbiology, 143(3), 183-189. http://dx.doi.org/10.1016/j.ijfoodmicro.2010.08.015

Soylu, E. M., Soylu, S., \& Kurt, S. (2006). Antimicrobial activities of the essential oils of various plants against tomato late blight disease agent Phytophthorainfestans. Mycopathologia, 161, 119-128. http://dx.doi.org/10.1007/s11046-005-0206-z

Soylu, E. M., Yiğitbaş, H., Tok, F. M., Soylu, S., Kurt, S., Baysal, Ö., \& Kaya, A. D. (2005). Chemical composition and antifungal activity of the essential oil of Artemisia annua L. against foliar and soil-borne fungal pathogens. Journal of Plant Diseases and Protection, 112, 229-239.

Soylu, S., Yigitbas, H., Soylu, E. M., \& Kurt, S. (2007). Antifungal effects of essential oils from oregano and fennel on Sclerotiniasclerotiorum. Journal of Applied Microbiology, 103, 1021-1030. http://dx.doi.org/10.1111/j.1365-2672.2007.03310.x

Tao, S., Zhang, S.,Tsao, R., Charles, M., Yang, R., \& Khanizadeh, S. (2010). In vitro antifungal activity and mode of action of selected polyphenolic antioxidants on Botrytis cinerea. Archives in of Plant Protection and Phytopathology, 43(16), 1564-1578. http://dx.doi.org/10.1080/03235400802583834

Ultree, A., Bennink, M. H. J., \& Moezelaar, R. (2002). The phenolic hydroxyl group of carvacrol is essential for action against the food-borne pathogen Bacillus cereus. Applied and Environmental Microbiology, 68, 1561-1568. http://dx.doi.org/10.1128/AEM.68.4.1561-1568.2002

Vasinauskiene, M., Radusiene, J., Zitikaite, I., \& Surviliene, E. (2006). Antibacterial activities of essential oils from aromatic and medicinal plants against growth of phytopathogenic bacteria. Agronomy Research, 4, 437-440. 